\title{
The effect of problem-based learning on nursing students' decision making skills and styles
}

\author{
Mona Thabet ${ }^{1}$, Eman EL-Sayed Taha ${ }^{* 2}$, Sahar Ahmed Abood ${ }^{1}$, Shadia Ramdan Morsy ${ }^{2}$ \\ ${ }^{1}$ Nursing Administration Department, Faculty of Nursing, Minia University, Egypt \\ ${ }^{2}$ Nursing Education Department, Faculty of Nursing, Alexandria University, Egypt
}

Received: October 8, 2016

DOI: $10.5430 /$ jnep.v7n6p108
Accepted: November 27, $2016 \quad$ Online Published: February 12, 2017

URL: http://dx.doi.org/10.5430/jnep.v7n6p108

\begin{abstract}
Decision making skill is deemed to be a key feature of the nurse's role in today's health care organizations. Thus, educators should use innovative teaching strategies that grow students' competence in problem-solving and decision making skills like problem-based learning (PBL). The aim of this study is to determine the effect of problem-based learning on nursing students' decision making skills and styles. A quasi-experimental research design was utilized. The sample consisted of 84 students from the fourth year in the Faculty of Nursing, Minia University. Two tools were used: Nursing Students' Decision Making Skills Scale and Nursing Students' Decision Making Style. This study revealed that the mean scores of decision making skills in the study group students increased before and after applying PBL (before: $71+8.5$, after: $116.3+10.4$ ) with a statistical significant difference $(p=.001)$. There was no statistical significant differences between the study and control groups $(p=1.000)$ before intervention. The most dominant decision-making style among the study and control groups in relation to before and after applying PBL was a behavioral decision style with no statistical significant differences. This study concluded that using PBL has a curial role in developing and improving nursing students' decision making skills; however, it has no effect on decision-making style.
\end{abstract}

Key Words: Problem-based learning, Decision making skills, Decision making styles, Nursing students

\section{INTRODUCTION}

Many of the current graduates still lack many skills like communication skills, creativity, analytical and critical thinking skills, problem-solving skills and decision-making skills. Therefore, there is a sturdy requirement of higher education institutions to focus on training future graduates to be more adaptable to the community needs, as well as to match between graduates' skills and the prerequisite skills for their future career. ${ }^{[1]}$

In traditional education, teaching is only oriented toward clarification, explanation, demonstration and evaluation; this was not an effective manner to develop and improve cog- nitive skills and abilities of students. ${ }^{[2]}$ In contrast, many challenges around the world need students who will be future citizens who will not only build their knowledge capacity but also will develop higher thinking skills such as critical thinking, problem solving, and decision making. ${ }^{[3]}$

Sequentially, a decisive component of the healthcare workforce fosters the nursing profession and deals efficiently and effectively with changes in the healthcare environment. ${ }^{[4,5]}$ Thus, to keep pace with the rapid healthcare environment changes, the nurse educators ought to continuously appreciate, review and update the educational curricula, strategies, and programs utilized to educate the new generation of nurs-

\footnotetext{
*Correspondence: Eman EL-Sayed Taha; Email: eman_said303@yahoo.com; Address: Nursing Education Department, Faculty of Nursing, Alexandria University, Egypt.
} 
ing students. In addition, using innovative teaching strategies can improve the development of higher level of nursing students' cognitive skills such as critical thinking, communication skills, clinical reasoning skills, problem solving skills, and decision making skills. ${ }^{[6-8]}$

One of the most common innovative teaching strategies which are associated with the large body of literature that comes out of medical education is PBL (problem-based learning). ${ }^{[9,10]} \mathrm{PBL}$ is an inquiry based method like studentcentered approach that guides students to find the best solutions of real-world problems through cooperative group work. ${ }^{[11]}$

\subsection{Review of literature}

PBL is a small group teaching method that was developed to help learners acquire the knowledge, skills, and attitudes of a significant proportion of a course or curriculum. ${ }^{[12]}$ The first definition of PBL was given by Barrows and Tamblyn (1980) "the learning that results from the process of working toward the understanding or solving a problem". ${ }^{[13]} \mathrm{PBL}$ is student (learner)-centered approach that fosters learners to search, combine between theory and practice by utilizing knowledge and skills to evolve a viable solution to the problem. ${ }^{[14]}$

PBL helps students define their needs to learn, develop a list of main points about the problem, determine what they already understand, what they need to investigate, and then acquire and apply the missing knowledge. ${ }^{[15,16]}$ In addition to the fact that PBL is collaborative, communicative and cooperative, it also allows students to work in small groups (6 to 8 or 5 to 7 students) with a high level of interaction, peer teaching and group presentations depending on themselves. $^{[17]}$

The environment in PBL develops self-control in students and enables them to see multidimensional events with a deeper perspective. In PBL, there is a clinical reasoning process which develops problem-solving skills including hypothesis generation, questioning, analysis, problem synthesis and decision-making. ${ }^{[18]}$ It encourages students to learn new materials and concepts when solving problems. It unites theory with practice, as it allows students both to merge their old knowledge with new knowledge and to develop their judging skills in a specific discipline environment. Furthermore, students can acquire the skills of time management, data collection, report preparation and evaluation. ${ }^{[19]}$

Moreover, learning in PBL helps students share one's ideas with each other which improves thinking and deepens understanding. ${ }^{[14,20]}$ PBL creates opportunities for students to interact with the teacher and their peers, which further promotes their conflict resolution skills as well as facili-

Published by Sciedu Press tates a greater student motivation, broadens the use of a variety of learning resources and encourages team building and group working, self-directed work, ${ }^{[21,22]}$ and communication skills. ${ }^{[23-25]}$

Furthermore, PBL gives room to students to search for knowledge and information to solve problems, thus allowing them to learn and acquire the problem solving skills. In addition, when students solve such problems, they generate hypotheses and face multiple alternatives or solutions to the problem in which they should choose the best one from these alternatives or solutions; thus, such students can acquire decision-making skills. ${ }^{[26-29]}$

Decision-making is an essential aspect of management, and a vital ability for the practice of nursing that enables nurses to perform their complex responsibilities. Decision-making is a behavior displayed when selecting and implementing a course of action from among alternatives with the purpose of dealing with a particular situation or problem. ${ }^{[30,31]}$ Furthermore, decision-making is a process that chooses a preferable option or a course of actions from a set of alternatives on the basis of given criteria or strategies. It is the process of examining possible options, comparing them, and choosing a course of action. ${ }^{[32,33]}$

Decision-making skills are enhanced and developed through a process of decision-making. Firstly, one should identify the problem or the opportunity. ${ }^{[34]}$ Then, he/she should think up alternative solutions. After that, he/she should evaluate the alternatives and select a solution. Alternatives should be evaluated not only according to cost and quality but also according to ethics, feasibility and their effectiveness. ${ }^{[34,35]}$ Finally, he/she should implement and evaluate the chosen solution. To ensure the success of implementation, there is a need to do two things: plan carefully and be sensitive to those affected. While evaluating the decision made, if the action does not work, one can give it more time, change it slightly, try another alternative, or start over again. ${ }^{[36]}$

There are four common decision-making styles according to Rowe et al. (1982) analytical, conceptual, behavioral, and directive. Decision-making style can be rational or intuitive, and it can also exhibit a higher or lower degree of tolerance for ambiguity. ${ }^{[37]}$ In the directive style, the leader is supposed to have sufficient information to evaluate relevant options and make an effective decision by oneself. This style has low tolerance for ambiguity and is oriented toward task and technical concerns in making decisions. ${ }^{[38]}$

In analytical style, not only do the leaders possess sufficient information, but they need to obtain more information and alternatives skills from others as well. This style has much 
higher tolerance for the ambiguity and is characterized by its tendency to overanalyze the situation. ${ }^{[34,38]}$ In the conceptual style, the leader explains the situation to the group, and together they generate and evaluate many possible solutions. People adopting a conceptual style have high tolerance for ambiguity and tend to focus on the people or social aspects of work situation. ${ }^{[38,39]}$ Regarding the behavioral style, the leader explains the situation to the group or individuals and provides the relevant information. Together they attempt to reconcile differences and negotiate a solution that is acceptable to all parties. Of all the four styles, most people are mostly oriented toward the latter. ${ }^{[34,38,40]}$

\subsection{Aim of the study}

The present study aims to determine the effect of problem -based learning on nursing students' decision-making skills and styles, and identify the relationship between nursing students' decision-making skills and styles.

\subsection{Research hypothesis}

- Students who are involved in problem-based learning strategy will exhibit higher decision-making skills.

- Students who have analytical decision making styles will exhibit higher decision-making skills.

\section{MAterials AND MethodS}

\subsection{Research design}

A quasi-experimental research design was utilized.

\subsection{Participants}

The study subjects comprised of 4th year nursing students enrolled in Nursing Administration Department, Faculty of Nursing, Minia University during the first semester of the academic year (2014-2015). The total number of the students was 84 divided randomly into two equal groups "study and control", each of which contains 42 students.

\subsection{Ethical consideration}

An informed consent was obtained from the administrative authorities, as well as nursing students and instructors after explaining the aim of the study. The participation was on a voluntary basis, thus giving such students an opportunity to refuse to participate in the study. In addition, the confidentiality, anonymity and privacy were assured to the students through using code numbers.

\subsection{Tools}

Two tools were used for the data collection. The first one named Nursing Student's Decision Making Skills Scale was developed by Griffin and Van Fleet $(2012)^{[41]}$ to measure the nursing students' decision making skills. It includes 30 items with five points Likert scale ranged from "not true at all (1) to completely true (5)". The scoring system ranged from 30 to 150 . The higher the score, the higher the level of decision making skills.

The second tool named Nursing Student's Decision Making Style was developed by Rowe et al. (1982) ${ }^{[37]}$ to measure four nursing students' decision making styles which were (directive, analytical, conceptual, and behavioral). It consists of 20 questions with four answers, distributed in four columns, each of which represents one decision making style. The students had to read each question on the left-hand side and score each response on the same line according to which alternative is the closest to the way they think or feel. Each question is answered by assigning values as follows: ( $8=$ When question is most like to me, $4=$ When question is moderate like to me, $2=$ When question is slightly like to me, and $1=$ When question is least like to me). The students' styles were determined according to the high score of dominant or very dominant column.

\subsection{Data collection}

A personal and academic sheet, as well as study tools questionnaire were used for data collection. The data were collected at the beginning and the end of the first semester of the academic year (2014/2015).

\subsection{Procedures}

(1) An official permission from the Dean of Faculty of Nursing, and head of the Nursing Administration Department, Minia University was obtained to allow data collection from students.

(2) Tools I, and II were tested for their reliability by using the Cronbach's Alpha test, the tools were reliable and the coefficient value were $0.85,0.71$ respectively.

(3) The tools and the problems were submitted to 11 experts in the related fields to determine their applicability and content validity.

(4) A pilot study was conducted on 10 participants to ascertain the clarity and applicability of the tools. The pilot study was excluded from the study subject.

(5) Data were collected throughout a period from October 2014 to December 2014.

(6) Students were divided randomly into two equal groups (study and control).

(7) The control group was trained by using the conventional methods and the study group was trained by using PBL.

(8) The actual study was conducted in three phases: planning, implementation, and evaluation phase.

ISSN 1925-4040 E-ISSN 1925-4059 
(9) Phase (I) Planning included four parts: preparation of researcher, development of PBL scenarios, preparation of learning environment, and preparation and training of students.

A. Preparation of researcher included developing handouts about the four Nursing Administration topics used in the study (change, delegation, power, and team building), which are related to Nursing Administration curriculum content.

B. Development of PBL scenarios: four PBL scenarios about four topics were developed using the textbooks and electronic resources.

C. Preparation of learning environments: the learning environment in which the study was conducted and all needed resources were prepared.

D. Preparation and training of students: the students in the study group (42 students) were divided into 5 sub-groups. The students were trained to the PBL technique and decision making process by using one PBL scenario (power problem). It lasted for four sessions: every session lasted for about 2 to 4 hours.

(10) Implementation phase was conducted by using three PBL scenarios. It took three weeks: one problem per week (change, delegation, and team building respectively). The three scenarios were assigned to each sub-group. Each scenario lasted for four sessions; the session lasted for about 2 hours.

(11) Evaluation phase: post-test was done after the third scenario using tools I and II.

\subsection{Statistical analysis}

After data were collected, they were revised, coded and fed to the statistical software SPSS version 16. The given graphs were constructed using Microsoft Excel software. All statistical analysis was done using two tailed tests and alpha error of 0.05. $p$ value less than or equal to .05 is considered to be significant. The following statistical tests were used:

A. Descriptive statistics: Including the means with standard deviation and percentage to describe the scale and categorical data.

B. Analysis of numeric data: One-Sample KolmogorovSmirnov Test: a procedure that compares the observed cumulative distribution function for a variable with a specified theoretical distribution which was the normal distribution at the current data (testing for distributional assumption of numerical data).

Mont Carlo exact test and Fishers exact test: they are alternatives for the Pearson's chi square test if there were many

Published by Sciedu Press small expected values.

Marginal Homogeneity test: It is a non-parametric statistical test that is used to compare frequencies of categories for items measured at different study phases (before and after intervention) where the item responses are multichotomus (low, moderate and high).

Mc-Nemar test: It is a non-parametric statistical test that is used to compare frequencies of categories for items measured at different study phases (before and after intervention) where the item responses are dichotomous (Yes, No).

\section{RESULTS}

This study displayed that both the study and control groups approximately matched each othr in their personal profile data with no statistical significant difference (see Table 1).

Table 2 illustrated that before using PBL, the mean scores of students' decision making skills in both the study and control groups were almost the same $(71+8.5,70+6.7$ respectively $)$ with no statistical significant differences between the study and control groups $(p=1.000)$. While after the intervention, the mean scores of the students' decision making skills in the study group increased to be $(116.3+10.4)$ but in the control group they became $(73.5+7.4)$ with statistical significant differences between the study and control groups $(p=.001)$.

Table 3 showed that before and after intervention, the most common decision-making style among the study and control groups was the behavioral style with no statistical significant differences between the study and control groups. Besides, it was observed that the analytical decision making style in the study group increased from (5\%) before intervention to (19\%) after intervention. However, it was noted that this style decreased from (14.3\%) before intervention to $(7.7 \%)$ after intervention in the control group.

In Table 4, it was observed that more than half of the students who had behavioral decision making style (56.3\%) had low decision making skills before intervention, while the majority (71.9\%) of them had high decision making skills after intervention. In addition, it was noted that all students (100\%) who had analytical decision making style had low decision making skills before intervention, while the majority $(87.5 \%)$ of them had high decision making skills after intervention. There were no statistical significant difference between decision-making styles and skills before or after intervention in the study group.

\section{Discussion}

Problem-based learning is one of the most important innovative teaching strategies that can foster students' skills like 
critical thinking, problem solving and decision-making. ${ }^{[42,43]}$ Therefore, the present study is unique and new in Egypt. It sheds the light on the effect of PBL strategy on the nurse students' decision-making skills and styles.

The current study revealed that PBL affected significantly on study group students' mean scores of decision-making skills after intervention, while no significant change was noticed in control group mean scores of decision-making skills. These results may be due to PBL processes which help students work in small groups, share their knowledge, opinions, think with each other, search for solutions, and then solve problems together. In addition, applying PBL processes helps students have more points of view from their peers, and work independently under the guidance of the researcher who was available to students all the time.

Table 1. Distribution of nursing students among the study and control groups according to their personal profile

\begin{tabular}{|c|c|c|c|c|}
\hline \multirow{3}{*}{ Students Personal Profile } & \multicolumn{4}{|c|}{ Groups } \\
\hline & \multicolumn{2}{|c|}{ Study $(N=42)$} & \multicolumn{2}{|c|}{ Control $(\mathrm{N}=42)$} \\
\hline & No & $\%$ & No & $\%$ \\
\hline \multicolumn{5}{|l|}{ Age } \\
\hline $17<20$ & 2 & 4.8 & 2 & 4.8 \\
\hline $20<24$ & 40 & 95.2 & 40 & 95.2 \\
\hline \multicolumn{5}{|l|}{ Gender } \\
\hline Male & 17 & 40.5 & 16 & 38.1 \\
\hline Female & 25 & 59.5 & 26 & 61.9 \\
\hline \multicolumn{5}{|l|}{ Last certification } \\
\hline Secondary school & 40 & 95.2 & 35 & 83.3 \\
\hline Health Institute & 2 & 4.8 & 7 & 16.7 \\
\hline \multicolumn{5}{|l|}{ GPA } \\
\hline Excellent & 4 & 9.5 & 2 & 4.8 \\
\hline Very good & 7 & 16.7 & 5 & 11.9 \\
\hline Good & 19 & 45.2 & 23 & 54.8 \\
\hline Poor & 12 & 28.6 & 12 & 28.6 \\
\hline \multicolumn{5}{|l|}{ Previous work at hospitals } \\
\hline Yes & 18 & 42.9 & 15 & 35.7 \\
\hline No & 24 & 57.1 & 27 & 64.3 \\
\hline
\end{tabular}

Note. MCP: $p$ value based on Mont Carlo exact probability.

Table 2. Comparison between nursing students' decision making skills among the study and control groups before and after intervention

\begin{tabular}{|c|c|c|c|c|c|}
\hline \multirow{3}{*}{ Decision making skills } & \multicolumn{4}{|c|}{ Groups } & \multirow{3}{*}{ MCP } \\
\hline & \multicolumn{2}{|c|}{ Study $(N=42)$} & \multicolumn{2}{|c|}{ Control $(\mathrm{N}=42)$} & \\
\hline & No & $\%$ & No & $\%$ & \\
\hline \multicolumn{6}{|l|}{ Before intervention } \\
\hline Low & 22 & 52.4 & 22 & 52.4 & \multirow{3}{*}{1.000} \\
\hline Moderate & 20 & 47.6 & 20 & 47.6 & \\
\hline Mean \pm SD & \multicolumn{2}{|c|}{$71.0 \pm 8.5$} & \multicolumn{2}{|c|}{$70.5 \pm 6.7$} & \\
\hline \multicolumn{6}{|l|}{ After intervention } \\
\hline Low & 0 & 0.0 & 15 & 35.7 & \multirow{4}{*}{$.001^{*}$} \\
\hline Moderate & 13 & 31.0 & 27 & 64.3 & \\
\hline High & 29 & 69.0 & 0 & 0.0 & \\
\hline Mean \pm SD & \multicolumn{2}{|c|}{$116.3 \pm 10.4$} & \multicolumn{2}{|c|}{$73.5 \pm 7.4$} & \\
\hline$M H(p)$ & \multicolumn{2}{|c|}{$6.1(.001)^{*}$} & \multicolumn{2}{|c|}{$2.6(.058)$} & \\
\hline
\end{tabular}

Note. MCP: $p$ value based on Mont Carlo exact probability; MH: Test of Marginal homogeneity for related samples * $p<.05$ (significant). 
Table 3. Comparison between nursing students' decision making styles among the study and control groups before and after intervention

\begin{tabular}{|c|c|c|c|c|c|}
\hline \multirow{3}{*}{ Decision Making Styles } & \multicolumn{4}{|c|}{ Groups } & \multirow{3}{*}{ FEP } \\
\hline & \multicolumn{2}{|c|}{ Study $(N=42)$} & \multicolumn{2}{|c|}{ Control (N = 42) } & \\
\hline & No & $\%$ & No & $\%$ & \\
\hline \multicolumn{6}{|l|}{ Before intervention } \\
\hline Analytical & 2 & 5.0 & 6 & 14.3 & .251 \\
\hline Behavioral & 32 & 80.0 & 32 & 76.2 & .257 \\
\hline Conceptual & 10 & 25.0 & 9 & 21.4 & .104 \\
\hline Directive & 6 & 15.0 & 5 & 11.9 & .203 \\
\hline \multicolumn{6}{|l|}{ After intervention } \\
\hline Analytical & 8 & 19.0 & 3 & 7.7 & .118 \\
\hline Behavioral & 32 & 76.2 & 32 & 82.1 & .130 \\
\hline Conceptual & 12 & 28.6 & 12 & 30.8 & .654 \\
\hline Directive & 4 & 9.5 & 4 & 10.3 & .799 \\
\hline$p$ for Analytical & .147 & & .174 & & \\
\hline$p$ for Behavioral & .351 & & .427 & & \\
\hline$p$ for Conceptual & .741 & & .302 & & \\
\hline$p$ for Directive & .339 & & .859 & & \\
\hline
\end{tabular}

Note. FEP: $p$ value based on Fisher exact probability; $p$ : Adjusted $p$ value of Mc-Nemar test; N.B: Student may have more than one style.

Table 4. The relation between nursing students' decision making styles and decision making skills in the study group before and after intervention

\begin{tabular}{|c|c|c|c|c|c|}
\hline \multirow{3}{*}{$\begin{array}{l}\text { Decision making styles } \\
\text { before intervention }\end{array}$} & \multicolumn{4}{|c|}{ Decision making skills before-intervention in study group $(n=42)$} & \multirow{3}{*}{ FEP } \\
\hline & \multicolumn{2}{|c|}{ Low } & \multicolumn{2}{|c|}{ Moderate } & \\
\hline & No & $\%$ & No & $\%$ & \\
\hline Analytical & 2 & 100.0 & 0 & 0.0 & .214 \\
\hline Behavioral & 18 & 56.3 & 14 & 43.8 & .365 \\
\hline Conceptual & 4 & 40.0 & 6 & 60.0 & .214 \\
\hline Directive & 2 & 33.3 & 4 & 66.7 & .351 \\
\hline \multirow{3}{*}{$\begin{array}{l}\text { Decision making styles } \\
\text { after intervention }\end{array}$} & \multicolumn{4}{|c|}{ Decision making skills post-intervention in study group $(n=42)$} & \multirow{3}{*}{ FEP } \\
\hline & \multicolumn{2}{|c|}{ Moderate } & \multicolumn{2}{|c|}{ High } & \\
\hline & No & $\%$ & No & $\%$ & \\
\hline Analytical & 1 & 12.5 & 7 & 87.5 & .210 \\
\hline Behavioral & 9 & 28.1 & 23 & 71.9 & .478 \\
\hline Conceptual & 6 & 50.0 & 6 & 50.0 & .091 \\
\hline Directive & 1 & 25.0 & 3 & 75.0 & .073 \\
\hline
\end{tabular}

Note. FEP: $p$ value based on Fisher exact probability; N.B: Students may have more than one style.

This result was in congruence with Nango and Tanka (2010) who agreed that the clinical decision-making of medical students was affected by the using PBL programs. ${ }^{[44]}$ The same finding with Abd El-Hay and Abd-Allah (2015) who found a significant improvement in nursing students' decision making skills after applying PBL strategy than before using it. ${ }^{[45]}$ Moreover, Al-Dress et al. (2015) mentioned that
PBL sessions helped students develop their decision-making skills. ${ }^{[46]}$ In addition, Harasym et al. (2013) agreed that PBL is the ideal format for refining students' ethical decisions and behaviors. ${ }^{[4]}$ In the same line, Sharma (2015) approved that PBL was an effective method to increase clinical decision making of nursing students. ${ }^{[48]}$ Jonassen (2011), as well, suggested that decision-making skills are enhanced through 
the use of PBL method, in which students can recognize, compare, and weigh the advantages and disadvantages of alternative solutions, then make a choice. ${ }^{[49]}$

The findings of the present study displayed that the majority of students among both the study group and control group had behavioral decision-making style before and after applying PBL strategy, which indicated that their styles weren't affected by applying PBL. These results may be due to many reasons and on top of them is that decision-making style is one of the individual characteristics and personality traits that are not easily affected by any intervention and done unconsciously. This explanation was in line with many researchers who stated that decision-making style is one's cognitive style that generally work and run in an unconscious manner and an individual may be aware or unaware of the findings of the information processing process. In addition, decisionmaking style is firstly a cognitive process that integrates the mental activities of perception, information processing or cognition. ${ }^{[50-52]}$

Misra and Srivastava (2012) added that, decision style is a usual manner or pattern that one uses in the decision-making process, and is based on levels of information or the way one receives and evaluates information. ${ }^{[53]}$ In addition, Jamian et al. (2011) and Mohammadi and Hajiheydari (2012) stated that decision style is the way a person uses information to formulate a decision. It is about preferences of individuals, not what one's capability is; therefore, no single type can be characterized as the best decision maker. ${ }^{[5,55]}$ Moreover, this explanation was in line with Bashir et al. (2013) whose participants were behavioral decision makers. ${ }^{[52]}$ In addition, the finding of this study was in congruence with Jamian et al. (2011) who indicated that the majority of participant in the study possessed very dominant and dominant behavioral styles. ${ }^{[54]}$ However, Senik et al. (2013) mentioned that individuals may typically have different decision making styles where one or more styles are dominant. They found that the conceptual and analytical styles are dominant, while the behavioral styles were the least utilized. ${ }^{[56]}$ Besides, Al-Omari (2013) found that the directive decision making style was mostly dominant among participants, followed by analytical, behavioral and conceptual. ${ }^{[57]}$

Moreover, changing students' style is not an easy task, it needs adequate or long time to affect the style and change it. In addition, this finding may be unlikely to happen due to the fact that the duration of this study applying PBL was too short, or the measurement of its effects on students' styles was measured in a very short timeframe. In this study, the duration of the PBL application was only five weeks which is a very short time to affect styles of students. This was in line with Choi et al. (2014) who found that there was no significant change in the study group who use PBL due to the short time that lasted for one semester (16 weeks). Furthermore, to have significant changes, the PBL programs should be applied for at least one year with students. ${ }^{[58]}$ Besides, Lim et al. (2010) found that there were no significant differences between the experimental group and control group in any of the decision making styles, as there was no sufficient time to affect decision making style. ${ }^{[59]}$ In contrast, Baker et al. (2007) suggested that PBL had an effect and could change the learning styles of nursing students. ${ }^{[60]}$

Furthermore, the result of this study shows slight changes in decision-making styles of the study group after the application of PBL. For instance, the analytical decision making styles increased from (5\% to 19\%) in the study group. This can be due to the work environment in PBL process, as students in PBL process need to be logical and systematic in their work procedure and follow specific steps even under stress, and need to solve problems by analysis and insight in their work and take the decision by themselves which can fit the analytical style of making decision. This interpretation was in line with many researchers who agreed that analytical decision makers have a strong need for achievement in the form of new challenges. They have greater tolerance for ambiguity, and encourage data collection and processing. They make decisions slowly because they want to examine the situation thoroughly and consider many alternatives systematically. ${ }^{[61,62]}$ Therefore, the analytical decision making style can be enhanced and developed by using PBL strategy.

Moreover, the result of the current study revealed that there were no significant differences between decision-making skills and decision-making styles before and after the application of PBL strategy among both the study and control groups. This may be due to the stability of decision-making styles, as no style of decision making is better than others as well as no single style can fit all situations. This was in line with Jamian (2011) and Rowe and Boulgarides (1992) who stated that the best method in making good decision is to use different styles according to available situations, problems and information. Thus, an effective manager is the one who has a combination of directive and behavioral decisionmaking styles. The combination of both styles will lead to an action-oriented manager. ${ }^{[54,62]}$ In contrast, Bavolar and Orosova (2015) found weak statistical significant relation between the decision-making styles and decision-making competencies. ${ }^{[63]}$

\section{Conclusion}

The current study concluded that PBL strategy is an effective and valuable teaching strategy. It has a curial and an 
important role in developing and improving nursing students' decision-making skills; however, it has no effect on students' decision-making style despite the fact that, the analytical

\section{REFERENCES}

[1] Neo M, Neo KT. Innovative teaching: using multimedia in a problembased learning environment. Journal of Educational Technology and Society. 2001; 4(4): 19-31. Available from: http://www. ifets . info/journals/4_4/neo.html

[2] Hsiao H, Chang J. A quasi-experimental study researching how a problem-solving teaching strategy impacts on learning outcomes for engineering students. World Transactions on Engineering and Technology Education. 2003; 2(3): 391-4.

[3] Temel S. The effects of problem-based learning on pre-service teachers' critical thinking dispositions and perceptions of problem-solving ability. South African Journal of Education. 2014; 34(1): 1-20. http://dx.doi.org/10.15700/201412120936

[4] National Advisory Council on Nurse Education and Practice (NACNEP). Addressing new challenging facing nursing education: solutions for a transforming healthcare environment. 8th Annual Report 2010. Available from: Http://Www.Google.Com.Eg/

[5] Swanson EA, Nicholson AC, Boese TA, et al. Comparison of selected teaching strategies incorporating simulation and student outcomes. Clinical Simulation in Nursing. 2011; 7(3): 81-90. http: //dx.doi.org/10.1016/j.ecns.2009.12.011

[6] Bradshaw M, Lowenstein A. Innovative teaching strategies in nursing and related health professions. 6th ed. United States of America: Jones \& Bartlett Learning Co. 2014; 6-10.

[7] Tinnon EA. Scavenger hunt: a creative teaching strategy to introduce pharmacological concepts and ethical concerns. Teaching and Learning in Nursing. 2014; 9(3): 104-7. http://dx. doi.org/10.1016 /j.teln.2014.03.004

[8] AL-Dossary R, Kitsantas P, Maddoxb P. The impact of residency programs on new nurse graduates' clinical decision-making and leadership skills: A systematic review. Nurse Education Today. 2014; 30(6): 1024-8. https://doi.org/10.1016/j.nedt.2013.10.006

[9] Gul RB, Boman JA. Concept mapping: a strategy for teaching and evaluation in nursing education. Nurse Education in Practice. 2006; 6(4): 199-206. http://dx.doi.org/10.1016/j.nepr.2006.0 1.001

[10] Opton L, Clark C, Wilkinson C, et al. Student-developed simulations: an innovative approach to teaching and learning. Clinical Simulation in Nursing. 2014; 10(2): 103-6. http://dx.doi.org/10.1016/j .ecns . 2013.05.014

[11] Oja KJ. Using problem-based learning in the clinical setting to improve nursing students' critical thinking: an evidence review. Journal of Nursing Education. 2011; 50(3): 145-51. https://doi .org/10 .3928/01484834-20101230-10

[12] Exley K, Dennick R. Small group teaching: tutorials, seminars and beyond. London: Routledge Flamer Co. 2004; 76-93. https: //doi.org/10.4324/9780203465066

[13] Barrows H, Tamblyn R. Problem-based learning and approach to medical education. New York: Springer Publishing Co., 1980; 1-18.

[14] Annerstedt C, Garza D, DeVoss C, et al. Researchable through problem-based learning. Journal of the Scholarship of Teaching and Learning. 2010; 10(2): 107-27. http://josotl. indiana.edu/a rticle/view/1745/1743

Published by Sciedu Press style was enhanced by using it.

\section{CONFLicts OF INTEREST Disclosure}

The authors declare that there is no conflict of interest.
[15] Tarhan L, Acar-Sesen B. Problem based learning in acids and bases: learning achievements and students' beliefs. Journal of Baltic Science Education. 2013; 12(5): 565-78. http://www.scientiasocial is. $1 \mathrm{t} / \mathrm{jbse} / \mathrm{q}=$ node $/ 319$

[16] Leary H, Walker A, Shelton B, et al. Exploring the relationships between tutor background, tutor training, and student learning: a problem-based learning meta-analysis. Interdisciplinary Journal of Problem-based Learning. 2013; 7(1): 40-66. http://dx. doi .org $/ 10.7771 / 1541-5015.1331$

[17] Tan OS. Problem-based learning pedagogies: psychological processes and enhancement of intelligences. Education Research Policy Practice. 2007; 6(2): 101-14. https://doi.org/10.1007/s106 71-007-9014-1

[18] Williams SM, Beattie HJ. Problem based learning in the clinical setting: A systematic review. Nurse Education Today. 2008; 28(2): 146-54. http://dx.doi.org/10.1016/j.nedt.2007.03.007

[19] Akinoglu O, Tandogan RO. The effects of problem-based active learning in science education on students' academic achievement, attitude and concept learning. Eurasia Journal of Mathematics, Science \& Technology Education. 2007; 3(1): 71-81.

[20] Lee T, Shenb P, Tsai C. Enhance low-achieving students' learning involvement in Taiwan's higher education: an approach via e-learning with problem-based learning and self-regulated learning. Teaching in Higher Education. 2010; 15(5): 553-65. http: //dx.doi.org/10.1080/13562517.2010.506999

[21] Seren S, Ustun B. Conflict resolution skills of nursing students in problem-based compared to conventional curricula. Nurse Education Today. 2008; 28(4): 393-400. http://dx.doi .org/10.1016/j.n edt. 2007.07.005

[22] Lesperance M. The effects of problem based learning (PBL) on students' critical thinking skills. Published Doctoral dissertation. Faculty of the Graduate School, University of North Carolina, 2008.

[23] Rowan CJ, McCourt C, Beake S. Problem based learning in midwifery - The students' perspective. Nurse Education Today. 2008; 28(1): 93-9. http://dx.doi.org/10.1016/j.nedt.2007.02. 014

[24] Albanese MA, Mitchell S. Problem based learning: a review of literature on its outcomes and implementation issues. Academic Medicine. 1993; 68(1): 52-80. https://www.ncbi.nlm.nih.gov/pubmed/ 8447896

[25] Willis SC, Jones A, Bundy C, et al. Small group work and assessment in a PBL curriculum: a qualitative and quantitative evaluation of student perceptions of the process of working in small groups and its assessment. Medical Teacher. 2002; 24(5): 495-501. http://dx.doi.org/10.1080/0142159021000012531

[26] Cassarino C. The impact of problem based learning on critical thinking and problem solving skills. Published doctoral dissertation. Fischler School of Education and Human Services, Nova Southeastern University; 2006. http://search.proquest.com/docview/30 4909910

[27] Marquis B, Huston C. Management decision making for nurses: 124 case studies. 4th ed. Philadelphia: Lippincott Williams \& Wilkins Co., 2003; 27-50. 
[28] Karatas I, Baki A. The effect of learning environments based on problem solving on students' achievements of problem solving. International Electronic Journal of Elementary Education. 2013; 5(3): 24968. https://doaj .org/article/63251d7294bf4b258c6f34f e567148a3

[29] Dochy F, Segers M, Bossche PV, et al. Effects of problem-based learning: a meta-analysis. Learning and Instruction. 2003; 13(5): 533-68 http://dx.doi .org/10.1016/S0959-4752(02)00025-7

[30] Marquis B, Huston C. Leadership roles and management functions in nursing. 7th ed New Delhi: Lippincott Williams \& Wilkins Co., 2012; 4-20.

[31] Abd-Elgilel S. Assessment of nurses' participation in the clinical decision making. Unpublished Master Thesis, Faculty of Nursing, Alexandria University; 2012.

[32] Rue L, Byars L. Supervision. 10th ed. New York: McGraw-Hill/ Irwin Co., 2010; 20-35.

[33] Wang Y, Ruhe G. The cognitive process of decision making. Journal of Cognitive Informatics and Natural Intelligence. 2007; 1(2): 73-85. https://doi.org/10.4018/jcini. 2007040105

[34] Kinicki A, Williams B. Management: a practical introduction. Boston: McGraw Hill Irwin Co., 2003; 208-43.

[35] Certo S. Modern management: diversity, quality, ethics, and the global environment. 7th ed. New Jersey: Prentice-Hall International Co., 1997; 153-73. PMid:9380859

[36] Sullivan E, Decker P. Effective leadership and management in nursing. 4th ed. California: Addison-Wesley Co., 1997; 265-81.

[37] Rowe A, Mason R, Dickel K. Strategic management and business policy. 1982. In: Robbins S, De Cenzo D. Fundamental of management: essential concepts and application. 2nd ed. New Jersey: Prentice Hall international INC Co. 1998; 133-61.

[38] Robbins S, Cenzo D. Fundamentals of management: essential concepts and applications. 2nd ed. New Jersey: Prentice-Hall International Co., 1998; 133-61.

[39] Certo S. Supervision: concepts and skill building. 4th ed. Boston: McGraw-Hill Irwin Co., 2003; 211-35.

[40] Rowe A, Davis S. Intelligent information system: meeting the challenge of the knowledge era. United States of America, Library of Congress Cataloguing in Publication Data Co., 1996; 24-40.

[41] Griffin R, Van-Fleet D. Management skills assessment and development. United states of America, South Western Cengage Learning Co; 2012; 272-39.

[42] Sendag S, Odabas FH. Effects of an online problem based learning course on content knowledge acquisition and critical thinking skills. Computers and Education. 2009; 53(1): 132-41. http: //dx.doi.org/10.1016/j.compedu.2009.01.008

[43] Flynn K. Fostering critical thinking skills in students with learning disabilities through online problem-based learning. International Conference e-Learning. 2014; 418-20. Available from: https: //archive.org/details/ERIC_ED557310

[44] Nango E, Tanaka Y. Problem-based learning in a multidisciplinary group enhances clinical decision making by medical students: A randomized controlled trial. Journal of Medical Dental Science. 2010; 57(1): 109-18.

[45] Abd El-Hay S, Abd-Allah S. Effect of Problem-Based Learning Strategy on Development of Problem Solving Skills among Undergraduate Nursing Students. Journal of Nursing and Health Science. 2015; 4(3): 1-13.

[46] Al-Drees A, Khalil M, Irshad M, et al. Students' perception towards the problem based learning tutorial session in a system-based hybrid curriculum. Saudi Medical Journal. 2015; 36(3): 341-8. https://doi.org/10.15537/smj.2015.3.10216
[47] Harasym PH, Tsai TC, Munshi F. Is problem-based learning an ideal format for developing ethical decision skills? Kaohsiung Journal of Medical Sciences. 2013; 29(1): 523-9. https://doi.org/10.101 $6 / j \cdot k j m s .2013 .05 .005$

[48] Sharma R. Effect of problem based learning on nursing students' clinical decision making and learning satisfaction. International Journal of Science and Research. 2015; 4(7): 163-5.

[49] Jonassen D. Supporting Problem Solving in PBL. Interdisciplinary Journal of Problem-based Learning. 2011; 5(2): 95-119. http: //dx.doi.org/10.7771/1541-5015.1256

[50] Scholl R, Schmidt C. Cognitive style and the MYERS -BRIGGS type inventory, 2001. Available from: http://www.uri.edu/resear $\mathrm{ch} / \operatorname{lrc}$

[51] Hirsh K, Hirsh E. Myers-Briggs Type Indicator Decision-Making Style Report, 2010. Available from: https : //www.cpp.com/pdf s /smp

[52] Bashir T, Shafi S, Ahmed HR, et al. Impact of cognitive and decision making style on resilience: an exploratory study. European Journal of Business and Management. 2013; 5(29): 92-107. Available from: http://iiste.org/Journals/index.php/EJB M/article/view/8759/9028

[53] Misra S, Srivastava K. Decision-making: path to effectiveness. Human Resource Management Research. 2012; 2(4): 46-52.

[54] Jamian LS, Sidhu GK, Aperapar PS. Managerial decision styles of deans: a case study of a Malaysian public. Asian Journal of University Education. 2011; 7(2): 59-80. https ://doi.org/10.1016/j . sbspro.2013.07.092

[55] Certo S. Supervision: concepts and skill building. 4th ed. Boston: McGraw-Hill Irwin Co. 2003; 211-35.

[56] Senik ZC, Sham RM, Abdul Rahman NN, et al. Academics as decision makers: what style do they adopt. Asian Journal of Teaching \& Learning in Higher Education. 2012; 4(1): 69-81.

[57] Al-Omari A. The Relationship between decision making styles and leadership styles among public schools principals. International Education Studies. 2013; 6(7): 100-10. http://dx.doi.org/10.55 39/ies. v6n7p100

[58] Choi E, Lindquist R, Song Y. Effects of problem-based learning vs. traditional lecture on Korean nursing students' critical thinking, problem-solving, and self-directed learning. Nurse Education Today. 2014; 34(1): 52-6. http://dx.doi.org/10.1016/j.nedt. 2013 .02 .012

[59] Lim JY, Kim MA, Kim SY, et al. The effects of a cognitive-behavioral therapy on career attitude maturity, decision making style, and selfesteem of nursing students in Korea. Nurse Education Today. 2010; 30(8): 731-6. http://dx.doi.org/10.1016/j.nedt . 2010.01. 014

[60] Baker CM, Pesut DJ, Mcdaniel AM, et al. Evaluating the impact of problem-based learning on learning styles of Master's students in Nursing administration. Journal of Professional Nursing. 2007; 23(4): 214-9. http://dx.doi.org/10.1016/j.profnurs. 20 07.01 .018

[61] Martinsons M, Davison R. Strategic decision making and support systems: Comparing American, Japanese and Chinese management. Decision Support Systems 2007; 43(1): 284-300. http: //dx.doi.org/10.1016/j.dss.2006.10.005

[62] Rowe A, Boulgarides J. Managerial Decision Making. New York: Macmillan Publishing Company; 1992.

[63] Bavolar J, Orosova O. Decision-making styles and their associations with decision-making competencies and mental health. Judgment and Decision Making. 2015; 10(1): 115-22. 